\title{
Planktonic algae abundance and diversity are similar in urban stormwater ponds of different geographic locations and natural shallow lakes
}

\author{
Greta Minelgaite $^{1}$ (D) Paul C. Frost ${ }^{2} \cdot$ Marguerite A. Xenopoulos $^{2} \cdot$ Diana A. Stephansen $^{1} \cdot$ Morten L. Fejerskov $^{1,3}$. $^{-}$ \\ Jes Vollertsen ${ }^{1}$
}

Published online: 13 March 2020

(C) The Author(s) 2020

\begin{abstract}
Elevated levels of different contaminants are typical to stormwater management ponds. Despite that, a number of works report stormwater ponds serving as habitats for a variety of biota. In this study we aimed to examine phytoplankton communities of urban ponds, as the basis of the aquatic food web, and compare them to those of natural shallow lakes. Stormwater ponds were selected from two distant geographic locations: three in Denmark and three in Canada. As a reference to natural systems, three Danish shallow lakes were sampled. The sampling was carried out in the spring, summer and fall of 2014. The phytoplankton communities in ponds were found to be at least as rich in taxa as natural shallow lakes. Their abundance and biovolume varied highly among the types of water bodies as well as in each pond or lake individually, depending on the sampling month. We did not find any significant differences among ponds and natural shallow lakes at the investigated taxonomic level, despite some distinction observed by multivariate DCA and CCA analyses. Little difference was found between Canadian and Danish ponds as well, even though they are separated by a large geographic distance. This study shows that stormwater ponds are habitats for diverse planktonic algae communities which have some similarities to those of natural shallow lakes. Also, the similarities observed between Danish and Canadian ponds indicate some consistence with the urban homogenization hypothesis, although this should be further looked into by future works examining a larger number and distinct types of ponds.
\end{abstract}

Keywords Stormwater pond $\cdot$ Phytoplankton $\cdot$ Shallow lakes $\cdot$ Diversity

\section{Introduction}

Stormwater ponds are common in urban areas as a best management practice for control and treatment of stormwater runoff. They serve as reservoirs for surface runoff from impervious surfaces and as water treatment facilities. A large number of studies have investigated the potential of stormwater ponds

Electronic supplementary material The online version of this article (https://doi.org/10.1007/s11252-020-00967-7) contains supplementary material, which is available to authorized users.

Greta Minelgaite

gretamin@gmail.com

1 Department of the Built Environment, Aalborg University, Thomas Manns Vej 23, 9220 Aalborg, Denmark

2 Department of Biology, Trent University, 1600 West Bank Drive, Peterborough, Ontario K9J 7B8, Canada

3 NIRAS, Ceres Allé 3, 8000 Aarhus, Denmark to treat the received runoff with respect to the pollutant removal processes (Bayley 2007; He and Marsalek 2014), and the fate of specific substances (Istenič et al. 2011; Stephansen et al. 2014). Less effort has been put into describing these as ecosystems from a biological or ecological point of view (Olding 2000; Vincent and Kirkwood 2014; Williams et al. 2013). It is becoming well acknowledged that urban stormwater ponds serve as habitats for a variety of biota (Bishop et al. 2000; Chiandet and Xenopoulos 2016) and could potentially contribute to the regional biodiversity (Le Viol et al. 2012). This seems to be the case even though the ponds are intended as treatment facilities and can receive a significant pollutant load covering a wide range of toxic substances (Pitt et al. 1995). Therefore, more attention needs to be paid to the potential of wildlife to inhabit and persist in such man-made aquatic ecosystems.

One of the first categories of organisms to colonize a water body is algae. Different groups of planktonic algae not only serve as food for organisms on higher trophic levels, but also serve as water quality indicators with some groups forming 
blooms of toxic cyanobacteria (Olding 2000). Only a limited number of studies describing phytoplankton communities in stormwater ponds have been published. It appears that the dominant groups of phytoplankton found in stormwater ponds is Cyanobacteria as demonstrated through microscopic counts (Vincent and Kirkwood 2014) or pigment analysis (Chiandet and Xenopoulos 2016), some of which might be responsible for the production of toxins. Given the dynamic nature of these communities, more studies are needed to understand their links with the hydraulic regime of the pond (Olding et al. 2000), stratification patterns of ponds (Song et al. 2013), and internal biogeochemical dynamics (Williams et al. 2013).

The objective of this study was to examine the phytoplankton communities of stormwater ponds with respect to their taxonomic diversity, abundance and biovolume. We selected ponds separated by the Atlantic Ocean but of similar climate conditions: three Danish ponds and three Canadian ponds, to test whether large geographic distances yield significantly different phytoplankton communities. Stormwater ponds are distinct from more natural water bodies due to their relatively shallow and nutrient-rich water columns and short water residence time. Nevertheless, by their size and appearance they somewhat resemble natural shallow lakes. With this work we also aimed to test whether pond phytoplankton communities could be comparable to those of natural lakes, despite their man-made nature and their intended purpose as stormwater management facilities. To do this, we selected three natural shallow lakes in Denmark.

\section{Materials and methods}

Three urban stormwater ponds and three natural shallow lakes located in northern and mid Jutland (Denmark), as well as 3 stormwater ponds in Peterborough (Ontario, Canada) were selected for the present study (Table 1).

Each pond and lake was sampled for water quality parameters and identification of phytoplankton communities. Sampling was conducted 3 times during the growth season: late April/May, July and September 2014. For data representation, each water body is given an ID, where P stands for pond, L for lake, DK for Denmark, and CAN for Canada. The ponds and lakes are numbered from 1 to 3 . A dash followed by $\mathrm{M}$, J, or $\mathrm{S}$ indicate the sampling month: late April/May, July and September, respectively.

\section{Field sampling and processing of water samples}

Water samples were collected from 5 locations distributed around the shore line of each pond and lake, approx. $20 \mathrm{~cm}$ below the water surface. The distance from the shore line for sampling was selected where the water depth was approx.
$70 \mathrm{~cm}$. Sampling locations are exemplified for ponds PDK1, PCAN1, and lake LDK1 in Fig. 1.

Samples from the 5 locations were pooled and mixed well for each water body. A subsample was preserved with Lugol's solution for later phytoplankton identification and enumeration. The water quality parameters: conductivity $\left(\mu \mathrm{S} \mathrm{cm}^{-1}\right)$, temperature $\left({ }^{\circ} \mathrm{C}\right)$ and dissolved oxygen $\left(\mathrm{mg} \mathrm{L}^{-1}\right)$, were measured on site at each of the 5 sampling locations with portable multimeters: WTW Multi 3430 set G (DK) and YSI-556 MPS (CAN). $\mathrm{pH}$ was measured on site as well, but only for Danish water bodies.

The pooled water samples were also analyzed for chlorophyll- $a\left(\mu \mathrm{g} \mathrm{L}^{-1}\right)$ and total phosphorus (TP, $\left.\mu \mathrm{g} \mathrm{L}^{-1}\right)$ both in Canadian and Danish water bodies. For Canadian ponds, procedures described by Song et al. (2013) and McEnroe et al. (2013) were followed. For Danish water bodies, TP was measured according to a method adapted from DS 292 (1985). For chlorophyll- $a$ extraction, water samples were filtered through $0.7 \mu \mathrm{m} \mathrm{GF} / \mathrm{F}$ filters, and a modified $90 \%$ acetone method was applied (adapted from Bellinger and Sigee 2010). Briefly, filters were homogenized in acetone, kept in dark for $20 \mathrm{~min}$, centrifuged at $2500 \mathrm{rpm}$ for $10 \mathrm{~min}$ and chlorophyll- $a$ measured using a spectrophotometer and absorption at $750 \mathrm{~nm}$ and $664 \mathrm{~nm}$ wavelengths. Water quality parameters, such as suspended solids, $\mathrm{NO}_{3}+\mathrm{NO}_{2}-\mathrm{N}$ and dissolved reactive phosphorus (DRP) were measured only for Danish water bodies. Water samples for DRP and $\mathrm{NO}_{3}+$ $\mathrm{NO}_{2}-\mathrm{N}$ measurements were filtered through $0.7 \mu \mathrm{m}$ filters. DRP and $\mathrm{NO}_{3}+\mathrm{NO}_{2}-\mathrm{N}$ were analyzed according to a method adapted from Standard Methods 4500-P (SM 1999) and according to DS 223 (1975) respectively. Total dissolved nitrogen (TDN), seston nitrogen (SN), total dissolved phosphorus (TDP) and seston phosphorus (SP) were measured for Canadian ponds only, as described in Song et al. (2013) and McEnroe et al. (2013). Parameters measured in Danish water bodies only or Canadian water bodies only were not included in the statistical analyses.

\section{Phytoplankton identification and enumeration}

Phytoplankton identification and enumeration was performed with an inverted microscopes (GX Optical XDS-3 and Motic AE31). Samples were analyzed using HydroBios or $\mathrm{KC}$ Denmark counting chambers. Depending on sample richness, either 5 or $10 \mathrm{~mL}$ chambers were used. When necessary, corresponding sample dilutions were made with demineralized water. Identification was attempted at genus level. In cases where this was not possible, organisms were assigned to other taxonomic levels, such as family, order, class, phylum, or to a group of unidentified organisms. Filamentous green algae were not included in the identification and counting. Counting was carried out either for a whole chamber at 100x magnification in order to capture the largest organisms, or in transects at $400 \mathrm{x}$ 


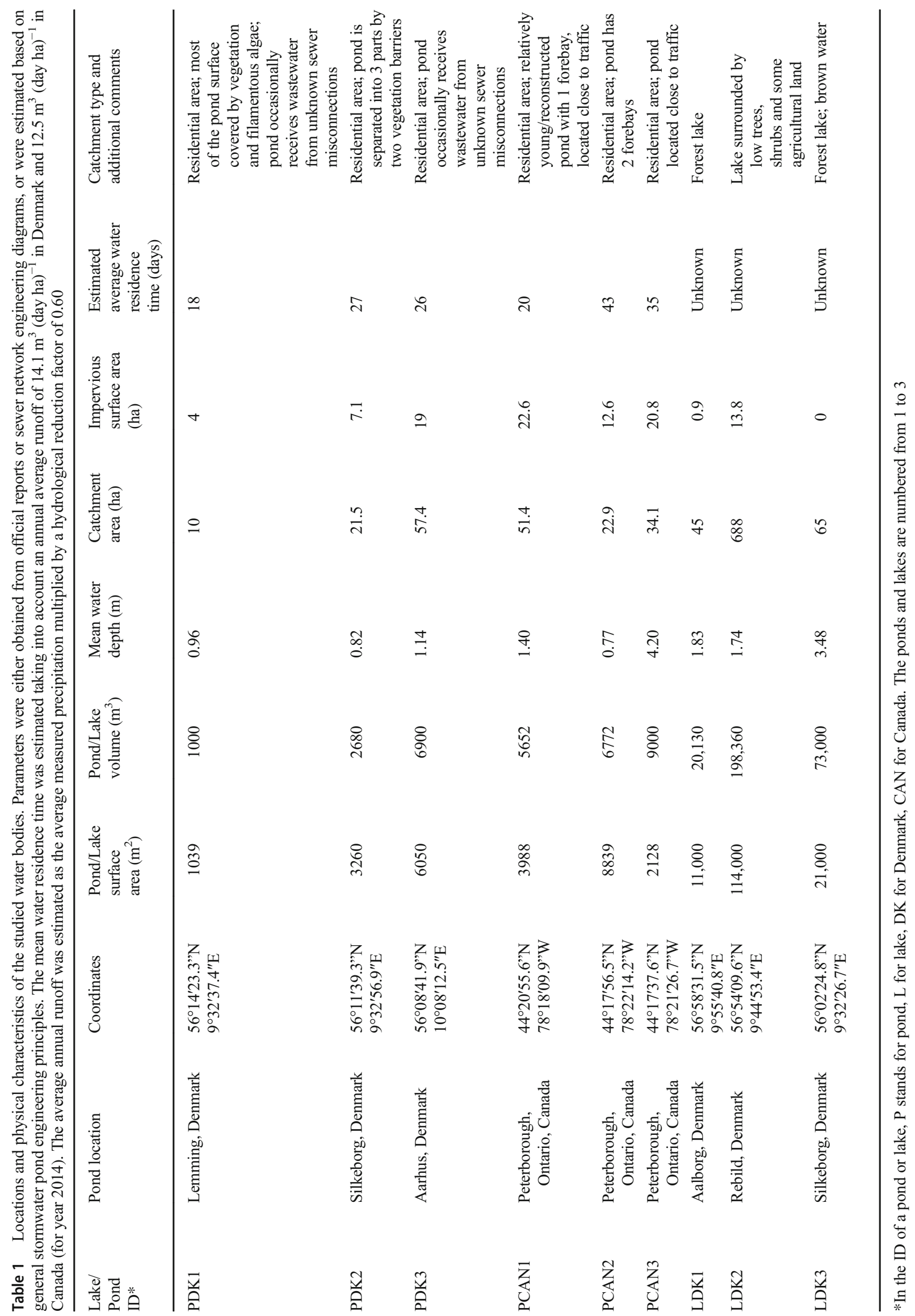


Fig. 1 Sampling locations in ponds PDK1, PCAN1 and lake LDK1
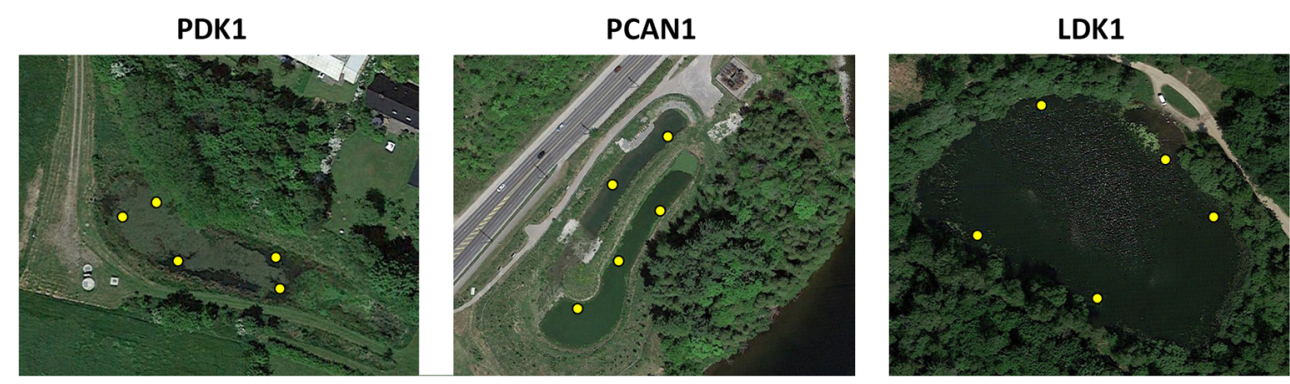

magnification when smaller organisms were counted. 600x magnification was used for identifications or counting of the smallest organisms. For some samples a somewhat uneven distribution was unavoidable, which was compensated by doing the counts in transects. Throughout, a single cell, colony, or filament was considered as a counting unit. Counting was continued until 100 counting units of each taxa/group was reached, but not in more than 7 transects. Organisms which did not reach a 100 , but significantly contributed to the total biovolume, were taken into account as well. 95\% of a sample (by biovolume) was counted, taking into account the most abundant taxa and taxa significantly contributing to the biovolume. An approximation of this contribution was done by counting all organisms in one transect, estimating their biovolume and that way distinguishing the significant sample taxa. Biovolume was estimated for every taxa or group of organisms assigning geometric formulas, as described in Hillebrand et al. (1999) and Lauridsen et al. (2005). For organism identification, John et al. (2011) was used as the reference key. Other identification keys by SPIPHES (1982), Tikkanen et al. (1992), Kristiansen and Nygaard (2001), Wehr et al. (2003), Cronberg and Annadotter (2006), Komarek and Anagnostidis (2007), Komarek (2008, 2013), and Guiry (2017) were used when additional specifications were necessary to identify a certain organism.

\section{Statistical analysis}

Statistical data analysis was carried out using Past v. 3.15 (Hammer et al. 2001; Legendre and Legendre 2012) and Sigmaplot v. 12.3 (Conover 1980; Snedecor and Cochran 1989; Systat Software 2016). One-way ANOVA or one-way ANOVA on ranks (depending on data normality) tests were performed on the number of taxa, total number of organisms as well as total biovolumes of the three types of water bodies Danish ponds, Danish lakes and Canadian ponds using Sigmaplot v 12.3. Algal community similarity among groups of ponds and lakes were tested using an analysis of variance on similarities (ANOSIM) between individual water bodies within the groups (Clarke and Warwick 1994). These analyses were performed in the Primer Software Package (Primer-E Ltd. 2016). The different water bodies were also compared by classical Bray-Curtis Cluster analysis and DCA analysis, intending to determine community and taxa similarity patterns among the ponds or lakes grouped together depending on their phytoplankton community composition using Past v. 3.15. The tests were performed using log-transformed relative abundance and biovolume data. Relationships among phytoplankton composition and water body related physical and chemical parameters were evaluated by Spearman's rank correlations in Past v 3.15. Phytoplankton community and water quality data sets were also submitted to CCA analysis in Past v. 4 in order to test whether there was any urban gradient effect on phytoplankton community structure. Lake and pond water quality indicators were also submitted to a PCA test in Past $v 4$ in order to determine which ones were the major drivers of the differences between ponds and lakes.

\section{Results}

\section{Physical and chemical water parameters}

Water quality parameters measured during the sampling period varied between Danish and Canadian water bodies (Table 2).

The measured conductivity varied over the season in the ponds, but not the lakes. It is likely related with runoff salt content due to road deicing applied during the cold season, although presence of other dissolved ions could have contributed to the measured values as well. With regard to nutrients, total phosphorus concentrations in Danish lakes were more similar to Canadian ponds than to the Danish ponds. Danish ponds had significantly (Tukey test, $p<0.05$ ) higher total phosphorus concentrations (48-230 $\mu \mathrm{g} \mathrm{L}^{-1}$ ), compared to the other water body types. Also, chlorophyll- $a$ concentrations were significantly (Tukey test, $\mathrm{p}<0.05$ ) higher in Danish ponds compared with Canadian ponds. In general, all concentrations increased during the summer and beginning of autumn, however, less markedly in Canadian ponds. Other parameters varied depending on the water body or sampling month and no significant differences were found among the three water body types, except for total suspended solids with significantly higher $(\mathrm{p}<0.05)$ concentrations measured in Danish ponds compared with lakes.

A multivariate PCA analysis performed with pond and lake water quality indicators showed that ponds and lakes were 
Table 2 Physical and chemical water quality parameters of the investigated water bodies. The given values are means of the sampling season (Late April/May, July and September \pm SD). NA - not analyzed

\begin{tabular}{|c|c|c|c|c|c|c|c|}
\hline \multirow[b]{2}{*}{ Pond/lake ID } & \multicolumn{7}{|c|}{ Measured parameter, sampling season mean $( \pm \mathrm{SD})$} \\
\hline & $\mathrm{pH}$ & $\begin{array}{l}\text { Conductivity, } \\
\mu \mathrm{S} \mathrm{cm}^{-1}\end{array}$ & $\begin{array}{l}\text { Dissolved } \\
\text { oxygen, } \mathrm{mg} \mathrm{L}^{-1}\end{array}$ & $\begin{array}{l}\text { Water } \\
\text { temperature, }{ }^{\circ} \mathrm{C}\end{array}$ & $\begin{array}{l}\text { Total suspended } \\
\text { solids, } \mathrm{mg} \mathrm{L}^{-1}\end{array}$ & $\begin{array}{l}\text { Chlorophyll- } \\
a, \mu \mathrm{g} \mathrm{L}^{-1}\end{array}$ & $\begin{array}{l}\text { Total phosphorus, } \\
\mu \mathrm{g} \mathrm{L}^{-1}\end{array}$ \\
\hline PDK1 & $6.4( \pm 0.4)$ & $103.3( \pm 38.9)$ & $4.1( \pm 2.7)$ & $16.9( \pm 1.6)$ & $20.0( \pm 9.0)$ & $111.0( \pm 69.3)$ & $168.0( \pm 63.3)$ \\
\hline PDK2 & $8.3( \pm 0.4)$ & $177.0( \pm 105.7)$ & $12.5( \pm 0.4)$ & $17.7( \pm 2.7)$ & $40.6( \pm 28.1)$ & $97.0( \pm 26.3)$ & $118.3( \pm 13.3)$ \\
\hline PDK3 & $7.8( \pm 0.2)$ & $579.7( \pm 251.3)$ & $8.0( \pm 1.0)$ & $16.3( \pm 2.9)$ & $11.3( \pm 6.2)$ & $44.7( \pm 29.5)$ & $115.3( \pm 47.7)$ \\
\hline PCAN1 & NA & $288.3( \pm 20.8)$ & $10.1( \pm 2.7)$ & $16.5( \pm 4.9)$ & NA & $5.0( \pm 1.4)$ & $23.7( \pm 2.1)$ \\
\hline PCAN2 & NA & $276.7( \pm 116.8)$ & $8.7( \pm 2.4)$ & $17.1( \pm 4.7)$ & NA & $27.3( \pm 8.2)$ & $59.0( \pm 19.8)$ \\
\hline PCAN3 & NA & $333.0( \pm 64.9)$ & $15.6( \pm 1.5)$ & $18.4( \pm 5.2)$ & NA & $27.3( \pm 9.2)$ & $51.3( \pm 15.8)$ \\
\hline LDK1 & $9.3( \pm 0.5)$ & $159.0( \pm 0.5)$ & $13.8( \pm 2.0)$ & $17.7( \pm 1.9)$ & $5.6( \pm 2.4)$ & $47.3( \pm 27.0)$ & $73.7( \pm 18.4)$ \\
\hline LDK2 & $7.3( \pm 0.8)$ & $84.3( \pm 1.2)$ & $9.9( \pm 0.8)$ & $16.7( \pm 2.1)$ & $4.3( \pm 2.1)$ & $41.7( \pm 31.5)$ & $55.3( \pm 9.1)$ \\
\hline LDK3 & $5.9( \pm 0.2)$ & $44.3( \pm 0.5)$ & $10.1( \pm 0.4)$ & $17.5( \pm 2.6)$ & $3.6( \pm 0.3)$ & $24.7( \pm 20.7)$ & $29.0( \pm 11.3)$ \\
\hline
\end{tabular}

quite different with respect to the measured conductivity and their catchment area. Such result is highly expected due to typically received higher runoff salt content by ponds and larger catchment areas of natural lakes.

\section{Phytoplankton taxonomic diversity, abundance and biovolume}

The identified phytoplankton taxa were ascribed to 9 phyla Chlorophyta, Cyanophyta, Euglenophyta, Cryptophyta, Dinophyta, Bacillariophyta, Chrysophyta, Xantophyta, and Haptophyta. In the whole data set a total of 101 taxa and specified groups of phytoplankton were observed: 14 to 57 in Danish ponds, 18 to 47 in Canadian ponds and 14 to 30 in Danish lakes (Table S1, supplementary material).

The majority of the phytoplankton taxa were present in all three types of the water bodies, such as, single-celled Chroococcales, desmids Closterium, Cosmarium and Stauraustrum of the order Zygnematales, Pseudanabaena filaments, cryptophytes, or pennate diatoms. Comparing ponds and lakes, several taxa or taxonomic groups of phytoplankton were more often observed both in Danish and Canadian ponds than in the Danish lakes. These included the green algae Ankistrodesmus, Acutodesmus, Desmodesmus, Monoraphidium, Pediastrum, Scenedesmus, Crucigeniella, Dictyosphaerium, all euglenophytes, and most of the chrysophytes, centric diatoms, and colonial or filamentous diatoms.

With respect to the geographic locations of the water bodies, three organisms from the green algae order Volvocales Eudorina, Gonium, and Pandorina - were only found in Canadian ponds and only observed a few times in Danish lakes. Also cysts of euglenophytes, ascribed to a group "cysts", were observed in one of the Danish ponds, PDK2, and one of the Danish lakes, LDK1, while they were abundant in the Canadian ponds.
One fifth of the identified taxa was ascribed to the phylum Cyanophyta, which comprises many species capable of producing toxins that may cause adverse effects on human health. Several of the identified cyanobacteria genera, namely Anabaena, Anabaenopsis, Lyngbya, Microcystis Oscillatoria, and Planktothrix are listed as some of the potential toxin-producing organisms with most significant impacts on human health (Chorus and Bartram 1999; WHO 2003). The presence of these genera varied during the sampling season. A slight difference was found between the analyzed ponds and lakes: in Danish ponds 0-4 of these genera were identified, in Canadian ponds 0-3, and in Danish lakes 1-2.

The highest numbers were counted for single-celled coccoidal and rod-shaped Chroococcales (Fig. S1, supplementary material), widespread picoplanktonic Cyanophyta, which are common in the plankton of ponds and lakes (John et al. 2011). In this study, they were dominating numbers of organisms in all samples from all water bodies. Several peaks of single cells from colonial organisms of Chlorophyta or Cyanophyta were observed in LDK3-M, LDK1-J, LDK1-S, PDK3-J, and PDK3-S. The total numbers of organisms showed a high variability among all water bodies and sampling months: from $5.7 \cdot 10^{2}$ organisms $\mathrm{mL}^{-1}$ to $5.5 \cdot 10^{5}$ organisms $\mathrm{mL}^{-1}$ for Canadian ponds, $1.9 \cdot 10^{4}-4.1 \cdot 10^{5}$ organisms $\mathrm{mL}^{-1}$ for Danish ponds and $2.9 \cdot 10^{3}-1.5 \cdot 10^{5}$ organisms $\mathrm{mL}^{-1}$ for Danish lakes.

The estimated total biovolume showed a high variability among the ponds and lakes (Fig. 2). The biovolume in the Danish lakes was found to be dominated by cyanophytes (up to $96 \%$ ) and chlorophytes (up to $43 \%$ ). Also, several peaks of cryptophytes were observed in LDK1 and LDK2 in May or dinoflagellates in LDK1 in July and September. In some of the months, Danish ponds were dominated by cryptophytes (up to 69\%), cyanophytes (up to 61\%), euglenophytes (up to $78 \%$ ) and chlorophytes (up to $80 \%$ ), while in Canadian ponds a larger part of the biovolume $(10 \%-15 \%)$ was composed of diatoms (PCAN1-M-J, PCAN2-M, PCAN3-M) or 

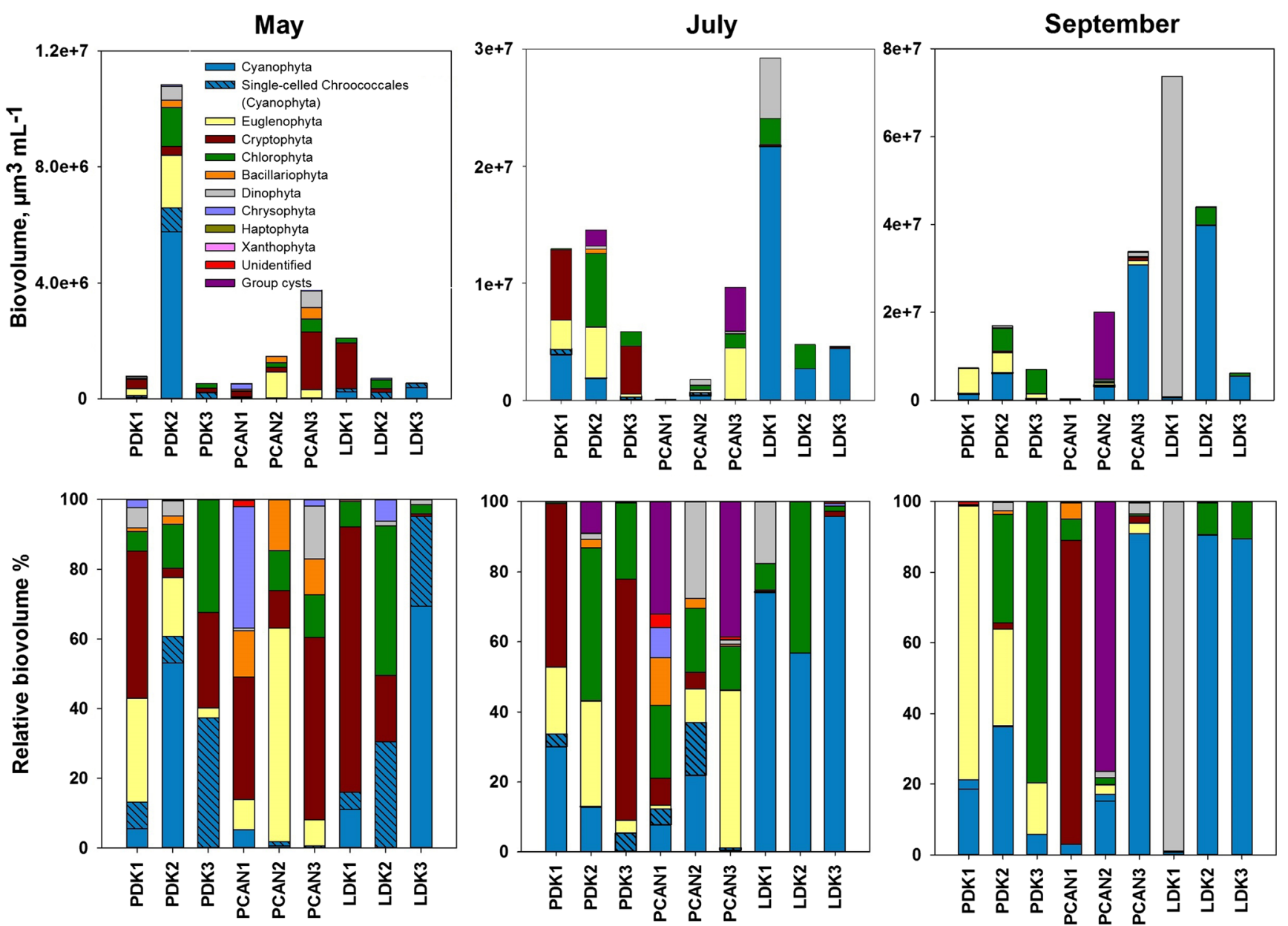

Fig. 2 Phytoplankton biovolume in Danish ponds, lakes, and Canadian ponds counted in late April/May, July and September. Note the differences in scales

chrysophytes (PCAN1-M-J, 35\% and 9\% respectively). An apparent contribution of euglenophyte cysts to the biovolume was also observed in Canadian ponds PCAN1-J, PCAN3-J, PCAN2-S, 32\%-39\% and 76\%, respectively.

With respect to the potential toxin-producing genera, blooms of Anabaena were observed in all Danish lakes in July and/or September. The genus contributed 54\%-90\% to the total biovolume. Microcystis colonies were also observed in LDK1$\mathrm{J}$-S, but to a smaller extent - up to $2 \%$. Although a slightly larger variety of these genera was present in Danish ponds, only PDK2 had a notable contribution to the phytoplankton biovolume by Anabaena (PDK2-M) and Microcystis (PDK2-S), 46\% and 26\% respectively. In Canadian ponds, potentially toxic genera (Microcystis, Oscillatoria, Planktothrix) comprised up to $7 \%$ of the total biovolume, with an exception of PCAN3-S, where 89\% of the biovolume were Microcystis colonies.

\section{Statistical analysis}

Total taxa numbers, total numbers of counted organisms and estimated total biovolumes in Danish lakes, Danish ponds and Canadian ponds for the three sampling months were not different between water bodies (ANOVA, $p>0.05, \mathrm{~F} \neq 1$ ). Similarities in algal communities among the three groups of water bodies for each sampling month were also tested using ANOSIM tests. Similar to the ANOVA tests, the ANOSIM test did not reveal any significant differences among the three types of the water bodies, neither with respect to number of organisms or biovolumes $\left(\right.$ ANOSIM, $\mathrm{p}_{\text {org }}=0.072 ; \mathrm{p}_{\text {biovol }}=$ 0.077).

The multivariate DCA test did not show distinct grouping of the three types of water bodies either (Fig. 3; Fig. S2, supplementary material). Only with respect to the DCA on the estimated biovolumes (Fig. 3), the two axes of the respective plot were found to explain $26 \%$ and $17 \%$ of the pond and lake distribution and have significant correlations with several pond and water chemistry parameters. Axis 1 was found to significantly correlate with the surface area of the water bodies $\left(\mathrm{r}_{\mathrm{s}}=-0.54 ; p=0.004\right)$, and mean water depth $\left(\mathrm{r}_{\mathrm{s}}=-0.42 ; p=\right.$ $0.03)$, while axis 2 correlated with chlorophyll- $a$ concentration $\left(\mathrm{r}_{\mathrm{s}}=0.5 ; p=0.008\right)$ and temperature $\left(\mathrm{r}_{\mathrm{s}}=0.48 ; p=0.01\right)$. To some extent, lakes were different from ponds, evidenced by their position on the lower part of axis 1 (Fig. 3). However, the observed differences are rather small, and it cannot be 
Fig. 3 DCA analysis based on relative biovolumes of different phytoplankton phyla and groups

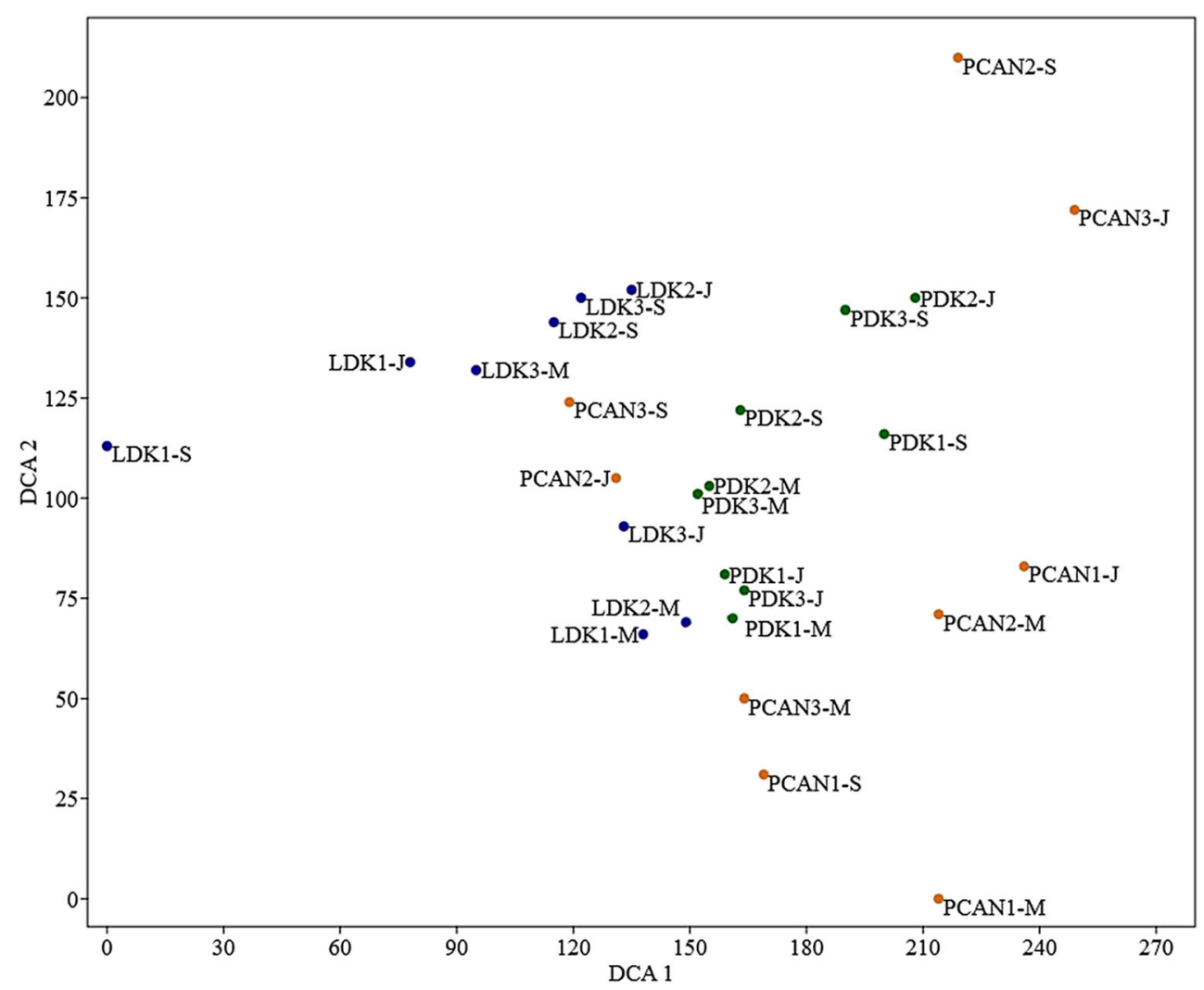

excluded that the observed differences between ponds and lakes are due to random variations.

A somewhat clearer result was obtained by CCA analyses (Fig. 4). Both when performed with community abundance and biovolume data, it could be observed that lakes grouped more distinctly from ponds, despite a few outliers. In Fig. 4 it can be seen that conductivity is one of the most important water quality indicators deciding the separation between the

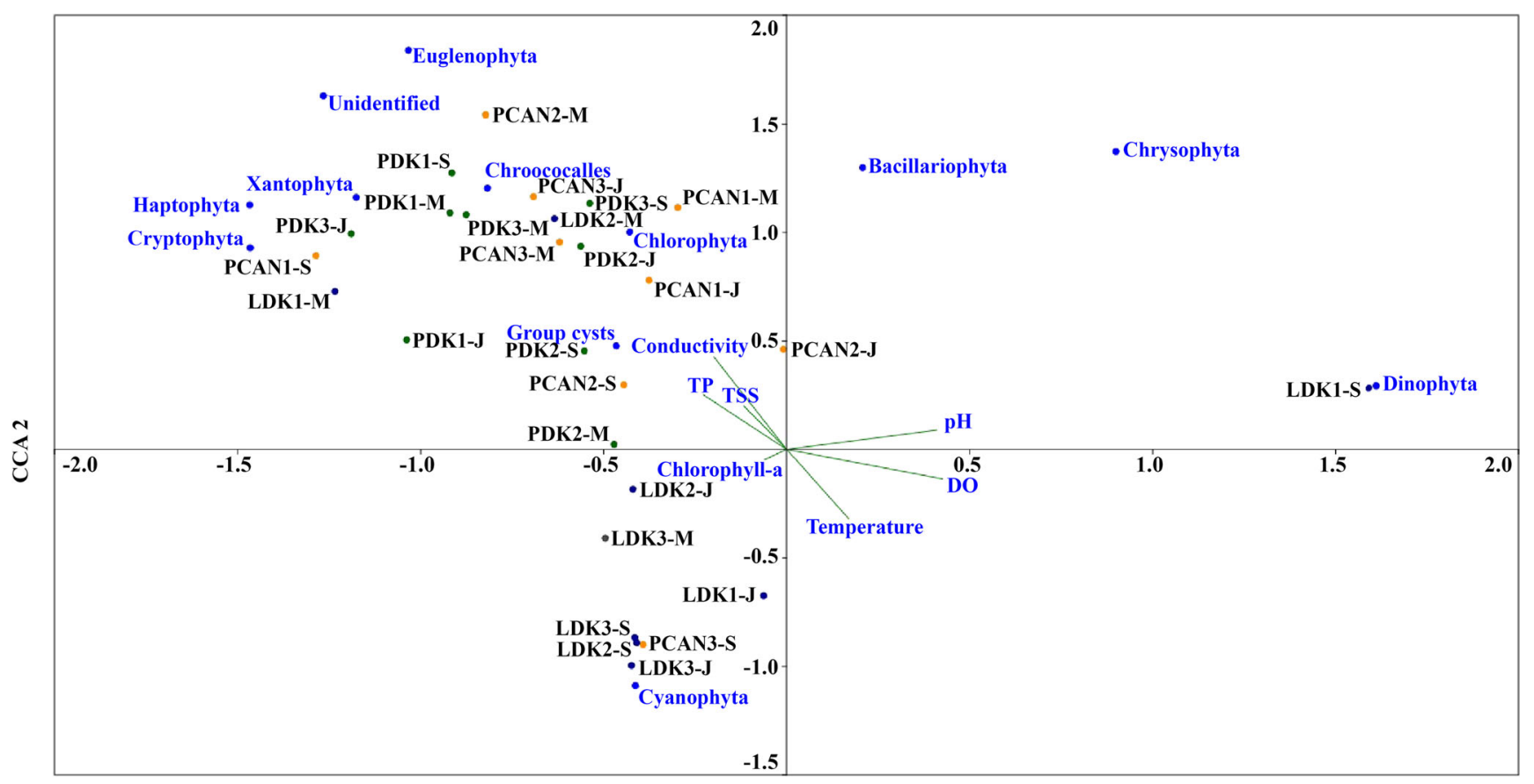

CCA 1

Fig. $4 \mathrm{CCA}$ analysis based on the water quality indicators and the estimated phytoplankton community biovolumes 
investigated ponds and lakes. Regarding the community composition, the main difference between ponds and lakes was a larger part of biovolume taken up by phyla Cyanophyta in lakes.

\section{Discussion}

Stormwater ponds and natural shallow lakes are fundamentally different water bodies. Ponds are designed and constructed according to the needs and requirements to manage surface runoff from impervious areas, while lakes are a consequence of long-term natural processes. Also, compared to lakes, ponds have a rather short water residence time (Table 1). It means that water exchange with new loads of nutrients and pollutants, collected from impervious surfaces, occurs on average every 2-4 weeks, while in lakes the water turnover is typically counted in years. On the other hand, with regard to their morphology, stormwater ponds somewhat resemble natural shallow lakes. Also, despite frequent inputs of nutrition or contamination, in time ponds serve as habitats for a variety of species of fauna and flora and form their own particular ecosystems.

We compared phytoplankton communities of stormwater ponds from distinct geographic locations with those of natural shallow lakes. We found similar communities in the investigated Danish and Canadian ponds, despite the measured water quality differences and the distance of about $6000 \mathrm{~km}$ between them. This result shows some consistence with the predictions of urban homogenization hypothesis (Groffman et al. 2014; McKinney 2006), even though such theory should be further tested with a larger number of different water bodies. Also, comparing ponds and lakes, despite the absence of statistical significance, an indication of distinction between natural and artificial environments was observed through the conducted multivariate analysis. The DCA and CCA analyses showed that most of the lake samples clustered and were somewhat separate from the ponds, which were more randomly interspersed (Fig. 3 and Fig. 4). This could be a result of differences in surface area and volume between ponds and lakes (DCA), as well as higher conductivity in ponds and Cyanophyta abundance in lakes (CCA). Alternatively, the homogenization aspect could be looked at as well, which points to biological communities in urban environments being more similar to each other than to the natural ones (Groffman et al. 2014).

Phytoplankton communities and their dynamics in urban ponds are likely to be influenced by urban stormwater flow which is expected to be of lower chemical quality compared to lakes. To our knowledge, only a few authors (e.g., Olding et al. (2000), Vincent and Kirkwood (2014), and Chiandet and Xenopoulos (2016)) have to a larger extent examined phytoplankton composition in stormwater ponds. These studies documented dominance of cyanobacteria and euglenophytes in most of these man-made ecosystems.
These past results were to a certain degree corroborated by the present study - the largest difference observed between stormwater ponds and natural shallow lakes was the presence of euglenophytes.

For the samples collected, euglenophytes varied from a relatively small to a big part of the biovolume in both Danish and Canadian ponds, while in the Danish lakes they contributed either very little to the biovolume or were absent. In the stormwater ponds, wind or rain induced resuspension of sediments, as well as presence of organic matter might result in the high euglenophyte abundance in the water column (Olding et al. 2000; Leander 2008; John et al. 2011). The ponds of the present study were also quite widely inhabited by submerged plants, especially PDK1 and PCAN3, which could have favored the observed euglenophyte abundance as well (Morris et al. 2006).

With respect to Cyanophyta (blue-green algae), we found a greater proportion of potential toxin-producers in the ponds than in the natural lakes namely, Anabaena, Anabaenopsis, Lyngbya, Microcystis Oscillatoria, and Planktothrix. Nevertheless, their contribution to the total phytoplankton biovolume was notable only in PDK2-M-S and PCAN3-S. The blooms of Anabaena were observed in all Danish lakes in July and/or September. Anabaena forms blooms in eutrophic waters and prefers environments with high phosphorus concentrations (Sandgren 1988). Thus, the observed blooms in lakes could be related with possible phosphorus inputs from the surrounding agricultural activities in Denmark. On the other hand, ponds are also characterized by high $\mathrm{N}$ and $\mathrm{P}$ concentrations (Chiandet and Xenopoulos 2011, 2016; Song et al. 2017), which is a preferred environment of bloomforming Microcystis. To a smaller or larger extent it was found present in most of the Danish and Canadian ponds.

Regarding the other phytoplankton phyla that we observed in the studied water bodies, only chrysophytes (golden-brown algae) and diatoms were found to exhibit differences among the lakes and ponds. Higher abundances of chrysophytes in ponds compared to lakes could be explained by their preference of smaller water bodies and ability to form cysts or shift nutrition acquirement strategies depending on the environmental conditions. Diatom presence in higher numbers in ponds could be favored by water column mixing (Sandgren 1988).

Overall, we observed that seasonal phytoplankton variability in each individual pond and lake was as high as the variability among the investigated types of water bodies. A similar result was observed in a study by Vincent and Kirkwood (2014). Their work did not show significant differences of algal biomass between the compared stormwater ponds and selected reference ponds. In our study, we found no statistically significant differences among the phytoplankton community composition and biovolume in ponds and lakes either. Future work with environmental genomics (e.g., Joly and Faure 2015; Rengefors et al. 2017) should be useful to better 
understand the relatedness of phytoplankton in urban ponds and lakes within and between geographic regions, such as those studied here.

Our study shows that ponds serve as habitats for a variety of phytoplankton taxa, and indicates that they are at least as diverse in algal taxa as natural shallow lakes. Ponds are dynamic systems with individual hydraulic regimes that rather frequently receive loads of pollutants (Hvitved-Jacobsen et al. 2010), which is generally not the case for natural lakes. Even though these pollutants could negatively affect the presence and survival of phytoplankton, the present study points in the direction that such effects are likely overshadowed by other environmental factors. For instance, high nutrient concentrations, irradiance, and foodweb structure together with the physico-chemical conditions in ponds likely create the environmental template against which these phytoplankton communities develop (Pal and Choudhury 2014).

This study also indicates that stormwater ponds, despite their use as technical water treatment systems, in time become habitats, and are to some degree comparable to natural shallow lakes. Similarly, Hassal and Anderson (2015) studied macroinvertebrate communities of stormwater ponds and natural wetlands and concluded that while the water quality of ponds was very different from that of the wetlands, the biodiversity of the richest ponds was similar to that of the natural wetlands. Also, Hassal (2014) in a review of the biodiversity and ecology of urban ponds has stated that "aquatic urban biodiversity appears to persist despite anthropogenic stressors".

Taking all into account, the analysis of phytoplankton functional diversity is increasingly being recognized as a better tool to describe and interpret the ecosystem processes (Borics et al. 2012). Whether it could provide a deeper insight into differences and similarities between man-made and natural aquatic systems should be addressed in future studies.

\section{Conclusions}

Phytoplankton communities of stormwater ponds - Danish and Canadian - and natural shallow lakes in Denmark were investigated in spring, summer, and autumn 2014, and were compared with respect to their taxonomic diversity, organism counts, and biovolume.

Phytoplankton taxa observed in ponds were found to be at least as diverse as in lakes. Their abundance and biovolume showed a high variability both among the types of water bodies, as well as in each pond or lake individually, depending on the sampling month. No statistically significant differences were found among the ponds and lakes at the investigated taxonomic level, although the multivariate DCA and CCA analyses showed some distinction between ponds and lakes, mainly driven by the measured conductivity and presence of Cyanophyta.
Our results did not show much difference between the Canadian and Danish pond phytoplankton communities, despite the distant geographic locations. Such findings point to the urban homogenization hypothesis, addressed in recent studies as a consequence of the expansion of cities and human-caused disturbance-similarities around the world. Nevertheless, in order to draw firm conclusions about such hypothesis future works should focus on examining a larger number and distinct types of ponds.

Overall, our study manifests that stormwater ponds in time become habitats for a diversity of planktonic algae, despite their man-made nature, and to a certain degree can be comparable to those of natural shallow lakes.

Open Access This article is licensed under a Creative Commons Attribution 4.0 International License, which permits use, sharing, adaptation, distribution and reproduction in any medium or format, as long as you give appropriate credit to the original author(s) and the source, provide a link to the Creative Commons licence, and indicate if changes were made. The images or other third party material in this article are included in the article's Creative Commons licence, unless indicated otherwise in a credit line to the material. If material is not included in the article's Creative Commons licence and your intended use is not permitted by statutory regulation or exceeds the permitted use, you will need to obtain permission directly from the copyright holder. To view a copy of this licence, visit http://creativecommons.org/licenses/by/4.0/.

\section{References}

Bayley M (2007) Constructed Ponds for the Treatment of Urban StormwaterBiotic Processes Influencing the Removal of Nitrogen, Phosphorus and Carbon. Thesis (PhD Doctorate), Griffith University, Brisbane. Retrieved from: https://www120.secure.griffith.edu.au/rch/items/a8863bb9-c598fb1a-9002-14402df2f79d/1/

Bellinger EG, Sigee DC (2010) Freshwater algae: identification and use as bioindicators. John Wiley \& Sons, Ltd, UK

Bishop CA, Struger J, Barton DR, Shirose LJ, Dunn L, Lang AL, Shepherd D (2000) Contamination and wildlife communities in Stormwater detention ponds in Guelph and the greater Toronto area, Ontario, 1997 and 1998. Part I - wildlife communities. Water Qual. Res. J. 35(3):399-435

Borics G, Tothmeresz B, Lukacs BA, Varbiro G (2012) Functional groups of phytoplankton shaping diversity of shallow lake ecosystems. Hydrobiologia 698:251-262. https://doi.org/10.1007/s10750-0121129-6

Chiandet AS, Xenopoulos MA (2011) Landscape controls of seston stoichiometry in urban stormwater management ponds. Freshw Biol 56: 519-529

Chiandet AS, Xenopoulos MA (2016) Landscape and morphometric controls on water quality in stormwater management ponds. Urban Ecosyst 19:1645-1663. https://doi.org/10.1007/s11252-016-0559-8

Chorus I, Bartram J (1999) Toxic Cyanobacteria in Water: A guide to their public health consequences, monitoring and management. World Health Organization, E \& FN Spon, an imprint of Routledge 11 New Fetter Lane, London EC4P 4EE. ISBN 0-419-23930-8

Clarke KR, Warwick RM (1994) Change in marine communities. An approach to statistical analysis and interpretation. National Environmental Research Council, Plymouth, UK 
Conover WJ (1980) Practical nonparametric statistics, 2nd edn. John Wiley \& Sons, New York

Cronberg G, Annadotter H (2006) Manual on Aquatic Cyanobacteria: A photo guide and synopsis of their toxicology. ISSHA and IOC of UNESCO, Copenhagen

DS 223 (1975) Vandundersøgelse. Bestemmelse af summen af nitrit- og nitratnitrogen

DS 292 (1985) Vandundersøgelse. Total phosphor. Fotometrisk metode

Groffman PM, Cavender-Bares J, Bettez ND, Grove JM, Hall SJ, Heffernan JB, Hobbie SE, Larson KL, Morse JL, Neill C, Nelson K, O’Neil-Dunne J, Ogden L, Pataki DE, Polsky C, Chowdhury RR, Steele MK (2014) Ecological homogenization of urban USA. Front Ecol Environ 12(1):74-81

Guiry MD (2017) Algaebase, SITE @ 1996-2017 M.D. Guiry. Available at: http://www.algaebase.org/

Hammer Ø, Harper DAT, Ryan PD (2001) PAST: paleontological statistics software package for education and data analysis. Palaeontol Electron 4(1):9pp http://palaeo-electronica.org/2001 1/past/issue1 01.htm

Hassal C (2014) The ecology and biodiversity of urban ponds. WIREs Water 1:187-206. https://doi.org/10.1002/wat2.1014

Hassal C, Anderson S (2015) Stormwater ponds can contain comparable biodiversity to unmanaged wetlands in urban areas. Hydrobiologia 745:137-149. https://doi.org/10.1007/s10750-014-2100-5

He C, Marsalek J (2014) Enhancing sedimentation and trapping sediment with a bottom grid structure. J Environ Eng 140(1):21-29

Hillebrand H, Durselen C-D, Kirschtel D, Pollingher U, Zohary T (1999) Biovolume calculation for pelagic and benthic microalgae. J Phycol $35: 403-424$

Hvitved-Jacobsen T, Vollertsen J, Nielsen AH (2010) Urban and Highway Stormwater Pollution - Concepts and Engineering. CRC Press/Francis \& Taylor Group

Istenič D, Arias CA, Matamoros V, Vollertsen J (2011) Elimination and accumulation of polycyclic aromatic hydrocarbons in urban stormwater wet detention ponds. Water Sci Technol 64(4):818-825

John DM, Whitton BA, Brook AJ (2011) The Freshwater Algal Flora of the British Isles, An Identification Guide to Freshwater and Terrestrial Algae, Second Edition. Cambridge University Press, ISBN 978-0-521-19375-7

Joly D, Faure D (2015) Next-generation sequencing propels environmental genomics to the front line of research. Heredity 114:429-430

Komarek J (2008) Cyanoprokaryota, Teil 1/ Part 1: Chroococcales, Süßwasserflora von Mitteleuropa, 19/1. Springer Spektrum, Spektrum Akademischer Verlag, ISBN 978-3-8274-2111-1

Komarek J (2013) Süßwasserflora von Mitteleuropa, Bd. 19/3: Cyanoprokaryota, 3. Teil / 3rd part: Heterocytous Genera. Springer Spektrum, Springer-Verlag Berlin Heidelberg, ISBN 978-3-8274-0932-4

Komarek J, Anagnostidis K (2007) Süßwasserflora von Mitteleuropa, Bd. 19/2: Cyanoprokaryota, Bd. 2 / Part 2: Oscillatoriales, Springer Spektrum, Spektrum Akademischer Verlag, ISBN 978-3-82741914-9, 759p

Kristiansen J, Nygaard G (2001) Dansk Planteplankton, Tredje Udgave. Gyldendal, ISBN13 9788700499126

Lauridsen TL, Søndergaard M, Jensen JP, Jeppesen E (2005) Undersøgelser i søer - NOVANA. Danmarks Miljøundersøgelser. 234 s. - Teknisk anvisning fra DMU nr. 22

Le Viol I, Chiron F, Julliard R, Kerbiriou C (2012) More amphibians than expected in highway stormwater ponds. Ecol Eng 47:146-154

Leander BS (2008) EOL - Encyclopedia of Life. Available at: http://eol. org/data objects/10116853

Legendre P, Legendre L (2012) Numerical Ecology, 3rd Edition. Elsevier. ISBN 9780444538680

McEnroe N, Williams CJ, Xenopoulos MA, Porcal P, Frost PC (2013) Distinct optical chemistry of dissolved organic matter in urban pond ecosystems. PLoS One 8(11):e80334. https://doi.org/10.1371/ journal.pone. 0080334
McKinney ML (2006) Urbanization as a major cause of biotic homogenization. Biol Conserv 127:247-260

Morris K, Bailey PCE, Boon PI, Hughes L (2006) Effects of plant harvesting and nutrient enrichment on phytoplankton community structure in a shallow urban lake. Hydrobiologia 571:77-91. https://doi. org/10.1007/s10750-006-0230-0

Olding DD (2000) Algal communities as a biological Indicator of Stormwater management pond performance and function. Water Qual Res J 35(3):489-503

Olding DD, Hellebust JA, Douglas MSV (2000) Phytoplankton community composition in relation to water quality and water-body morphometry in urban lakes, reservoirs, and ponds. Can J Fish Aquat Sci 57:2163-2174

Pal R, Choudhury AK (2014) An Introduction to Phytoplankton: Diversity and Ecology, Chapter 2: Physicochemical Environment of Aquatic Ecosystem. DOI https://doi.org/10.1007/978-81-3221838-8_2, (C) Springer India 2014

Pitt R, Field R, Lalor M, Brown M (1995) Urban Stormwater toxic pollutants: assessment, sources and treatability. Water Environment Research 67(3):260-275 http://www.jstor.org.zorac.aub.aau.dk/ stable/25044552

Primer-E Ltd (2016) Primer Software Package, version 7. Primer-E ltd, Plymouth, UK

Rengefors K, Kremp A, Reusch TBH, Wood AM (2017) Genetic diversity and evolution in eukaryotic phytoplankton: revelations from population genetic studies. J Plankton Res 39(2):165-179

Sandgren CD (1988) Growth and Reproductive Strategies of Freshwater Phytoplankton. Cambridge University Press, ISBN 978-0-52142910-8

SM (1999) Standard Method approved by American Public Health Association, American Water Works Association, Water Environment Federation. Available at: http://www.umass.edu/ mwwp/pdf/sm4500P-E.PDF

Snedecor GW, Cochran WG (1989) Statistical methods. Iowa State College Press, Ames, Iowa

Song K, Xenopoulos MA, Buttle JM, Marsalek J, Wagner ND, Pick FR, Frost PC (2013) Thermal stratification patterns in urban ponds and their relationships with vertical nutrient gradients. J Environ Manag 127:317-323

Song K, Winters C, Xenopoulos MA, Marsalek J, Frost PC (2017) Phosphorus cycling in urban aquatic ecosystems: connecting biological processes and water chemistry to sediment $P$ fractions in urban stormwater ponds. Biogeochemistry 132:203-212

SPIPHES - The Shiga Prefectural Institute of Public Health and Environmental Science (1982) The plankton of Lake Biwa (in Japanese)

Stephansen DA, Nielsen AH, Hvitved-Jacobsen T, Arias CA, Brix H, Vollertsen J (2014) Distribution of metals in fauna, flora and sediments of wet detention ponds and natural shallow lakes. Ecol Eng $66: 43-51$

Systat Software Inc. (2016) Sigmaplot v. 13.2. Systat Inc. San Jose, CA, USA

Tikkanen T, Willen T, Andersson B (1992) Sverige Statens naturvårdsverk. ISBN 9162011154, 9789162011154

Vincent J, Kirkwood AE (2014) Variability of water quality, metals and phytoplankton community structure in urban stormwater ponds along a vegetation gradient. Urban Ecosyst 17:839-853

Wehr JD, Sheath RG, Kociolek JP, Thorp JH (2003) Freshwater Algae of North America: Ecology and Classification (Aquatic Ecology) $1^{\text {st }}$ Edition. Elsevier Science (USA), ISBN 0-12-741550-5

Williams CJ, Frost PC, Xenopoulos MA (2013) Beyond best management practices: pelagic biogeochemical dynamics in urban stormwater ponds. Ecol Appl 23:1384-1395

World Health Organization (2003) Guidelines for safe recreational water environments, Volume 1: Coastal and Freshwaters. ISBN 924 1545801 